\title{
PROTECTION OF THE GEOLOGICAL HERITAGE OF THE AKTOBE OBLAST AND ITS USE FOR THE DEVELOPMENT OF GEOTOURISM
}

\author{
Aigul M. SERGEYEVA \\ K. Zhubanov Aktobe Regional University, Department of Geography \\ and Tourism, Aktobe, Kazakhstan, e-mail: sergeyeva.aigul@gmail.com \\ Akzhunus G. ABDULLINA \\ K. Zhubanov Aktobe Regional University, Department of Geography \\ and Tourism, Aktobe, Kazakhstan, e-mail: akshunus_a@mail.ru \\ Gulzhanat Zh. AKHMET \\ K. Zhubanov Aktobe Regional University, Department of Geography \\ and Tourism, Aktobe, Kazakhstan, e-mail: gulzhanat.akhmet@bk.ru
}

\section{Asima G. KOSHIM*}

Al-Farabi Kazakh National University, Faculty of Geography and Environmental Department of Cartography and Geoinformatics, Almaty, Kazakhstan, e-mail: asima.koshim@gmail.com

\section{Kuat T. SAPAROV}

L. N. Gumilyev Eurasian National University, Department of Physical and Economical Geography, Nur-Sultan, Kazakhstan, e-mail: k.sapar67@yandex.ru

\author{
Aigul Y. YEGINBAYEVA \\ L. N. Gumilyev Eurasian National University, Department of Physical \\ and Economical Geography, Nur-Sultan, Kazakhstan, e-mail: aeginbaeva@mail.ru
}

\begin{abstract}
Citation: Sergeyeva, A.M., Abdullina, A.G., Akhmet, G.Zh., Koshim, A.G., Saparov, K.T., \& Yeginbayeva, A.Y. (2022). PROTECTION OF THE GEOLOGICAL HERITAGE OF THE AKTOBE OBLAST AND ITS USE FOR THE DEVELOPMENT OF GEOTOURISM. GeoJournal of Tourism and Geosites, 40(1), 111-119. https://doi.org/10.30892/gtg.40113-809
\end{abstract}

\begin{abstract}
The purpose of the article is to study the geological objects of the Aktobe oblast and their use for the development of geotourism in the region. The analysis of published materials and field research data shows that the geological objects of the Aktobe oblast have all the properties and have much possibility to actively develop geotourism which depends on the level of local management and investments. The GAM method was used to assess geological objects. This method presents various estimates of main values (MV) and additional values (AV), which are very useful to preserve and develop the territory. As a result, the method provided different estimates in the development of geotourism.
\end{abstract}

Key words: geo-heritage, geological and geomorphological objects, Aktobe oblast, geotourism, protection of geological objects

\section{INTRODUCTION}

Due to the spread of COVID-19 all over the world and the closure of the borders of many countries for the entry of tourists, the interest in domestic tourism has increased, particularly, in territories with objects of geological and geomorphological value, i.e. in the active development of geotourism. Geotourism presents a type of innovative tourism that has been developing rapidly in recent years not only throughout the world, but in Kazakhstan too which enters the international tourism market as a potential region for the development of this type of activity and is recognized as an exciting and new direction of tourism on geological and geomorphological items of interest (Ghazi et al., 2013; Wendt, 2020). According to geotourism is defined as a form of nature tourism that gives special attention to the landscape and geology, to the preservation of cultural heritage and traditions, to the study of history, geography, to the popularity of the unique nature of the territory, to the investment promotion. Ólafsdóttir et al. (2018) and Štrba et al. (2020) defined geotourism as the understanding of the Earth sciences through the recognition and teaching of not only geological but also geomorphological features of the terrain and processes that are considered a resource for geotourism. Many scientists are of the opinion that geotourism can be understood as a new branch of applied geology focused on the geological environment and geomorphology which supports the development of alternative forms of tourism at the global level (Manyuk, 2016). Therefore the role of geo-protection increases which, thuswise, gets equal importance along with the protection of wildlife. This goal is also set forth in the definition of geotourism proposed by GaŁka (2019). Geological monuments are often called natural museums. They are of great scientific, cognitive and educational value. They also provide an opportunity to investigate the formation conditions of rocks making up

\footnotetext{
* Corresponding author
} 
the territory. In this case the rock exposures are monuments of geological history. And the more such objects are, the more indepth study can be given to the geological history, as in essence every bedrock exposure is exclusive and contains unique information about the long history of the earth's development and consequently it carries data of great scientific value. Each new geological manifestation is a specific discovery that changes modern ideas and to a significant degree expands the boundaries of our knowledge, including the vision into the depths of millions of years (Bruno et al., 2014; Gill, 2017).

Earlier the objects of geological heritage were classified into 21 type, as follows - stratigraphic, paleontological, sedimentation (sedimentary, sedimentological), igneous (including volcanic), metamorphic, mineralogical, orepetrographic, geochemical, seismic, structural-geological, paleogeographic, cosmogenic, geothermal, geocryological, geomorphological, hydrological-hydrogeological, engineering-geological, radiogeological, neotectonic, pedological (soil; including paleosoils) and historical-mining-geological (Kiernan, 2015). But most of the unique objects refer to a complex type, which includes two or more of the mentioned types as components. Although the combination of components of a complex type may vary, it is closely dependent on the local features of the geological environment and the conditions of its exposure on the surface, it seems essential to trace some of its patterns. It can be done through the analysis of fundamental scientific information about the main geological phenomena and the conditions of their localization (Mikhailenko et al., 2021; Williams et al., 2020). The importance of geo-diversity is represented by several important values:

scientific value;

- cultural value is associated with geomorphology - explanation of geological and geomorphological features with the use of supernatural forces and beings, historical and archaeological aspects of geo-diversity (the importance of geodiversity for ancient settlements or fortress systems, spiritual and religious aspects (Kubalíková, 2013);

- aesthetic value refers to the visual (and non-visual) appeal provided by geo-diversity, including the psychological impact on a person (Santangelo and Valente, 2020);

- economic and functional value is represented by the use of mineral resources, such as fuels, building materials; the use of landforms and the use of geo-diversity, respectively, geo-inheritance, geotouristic and geoeducational activities (Gray, 2004);

- scientific and educational value - is associated with understanding the origin of life and topographic forms, the evolution of the landscape and climate and paleogeographic reconstruction of structures (Reynard, 2005).

According to Panizza and Piacente (2008) and Pralong (1993), geomorphological objects are defined as geomorphological land forms and processes that have acquired aesthetic, scientific, cultural-historical and social-and-economic value due to human perception of geological, geomorphological, historical and social factors. In the context of tourism and recreation, these four different values can be regarded as exceptional components of the tourist value of a geomorphological object. All tourist goods, services and infrastructure produced and created on the basis of geomorphological land forms and processes result from the application of this value and its four components, which are understood in terms of the degree and modality of use. The articles of Comănescu and Dobre (2009), Coratza et al., (2018), Castaldini and Coratza (2017) describe the various stages of the inventory, they also address the problems related to the protection of geological heritage and suggest the management of geomorphosities. Panizza (2001), Comănescu et al., (2017), Badiali et al., (2018) discuss the issue of former land forms destroyed as a consequence of human activity, a key problem in urban areas where the original geomorphology was greatly affected by anthropogenic activity. The object of the study. The Aktobe oblast is located at the southern end of the Ural folded system and in regards to the geological structure is the most extensive and diverse region of Western Kazakhstan. Within this territory there are geological and geomorphological areas known as the Kazakh Urals and its province, the Peri-Caspian Depression and its margin. The region includes such natural landscape formations as the Or-Ilek Upland, Mugalzhary, the Northern Aral Sea region, the Irgiz river region and the western slope of the Turgai trough and their margins (Abdullin, 1981). As the data analysis demonstrates, over the long time the attendance of geological objects of the Aktobe oblast has been continuously growing. This growth is followed by a violation of nature management regulations, an excess of the recreational capacity of existing tourist routes which reduces the recreational and tourist value of the region. The excess of recreational capacity affects not only the tourist appeal of geological objects but also the preservation of landscapes, natural objects, as well as their functioning.

\section{MATERIALS AND METHODS}

Geological monuments of nature are selected natural objects representing a variety of geological events in the history of the Earth: reference and unique stratigraphic sections, specific elements of the landscape or their combinations expressing separate stages of the formation of the modern look of our planet, manifestations of minerals, mineral or rock associations, textural or structural features of rocks, traces of the vital activity of former organisms, underground water outlets, waterfalls, solutional caves and labyrinths, locations associated with the work of outstanding naturalists and pioneering explorers, evidence of early developments in the mining industry, sites of currently operating quarries, etc. (Hadmoko et al., 2021; Ilieș et al., 2020). Currently the most effective way to promote and protect geological heritage, especially for the purposes of tourism development, is, as mentioned above, geotourism. The concepts of geotourism and the geological and geomorphological diversity of objects are related to the geological environment in the abiotic sphere and highlight the role of geological elements. In this context geotourism plays a crucial role since it implements geological conservation in practice and contributes to its comprehension among the general public (Mirari and Benmlih, 2020). Ruban (2015) and Hurtado (2013) are of the same opinion stating that the protection of geological heritage depends on public opinion and that it is to be preserved. Therefore the best way to protect is to involve the population in the protection of geological heritage or geological monuments of nature and provide services to promote their value, unique character, advantages and ensure their protection to attract visitors. According to Newsome (2012) effective marketing and management of geotourism 
significantly contribute to the successful development of the region and, with proper local management, can make a successful contribution to its sustainable development, otherwise, the development of geotourism may pose a threat to the geological heritage. Some researchers suggest that the successful management of popular geotourism destinations requires to manage visitors and their number, to provide the interpretation of geotourism of high-quality and the corresponding infrastructure, as well as effective legislation (Pourfaraj et al., 2020). In the process of studying the best practices of geotourism development in protected natural areas we used a bibliographic method that opened the way to trace the evolution of the concept of geotourism from the genesis of this concept abroad till its use by regional researchers.

To write the article we used mainly field research materials (2012-2014, 2017-2018), statistical, reference, stock and literary materials on the natural conditions and resources of the region. Descriptive, comparative-geomorphological, statistical and cartographic research methods were used to characterize the geological monument of the territory. In addition the analysis and systematization of scientific publications and materials on the object and subject of research was carried out. A description and a tourist route for famous geological objects in the Aktobe oblast are presented (Segedin, 2002; Seyitov and Zhunisov, 2002). When 4 geological objects were determined the Geosite Assessment Model (GAM) was applied. GAM is widely used in Europe in various territories and has given good results in the assessment of geosites. The GAM method includes only expert opinions required for the preliminary development of geotourism in the Aktobe oblast. This method provides various assessments of the main values (MV) and additional values (AV), which are very useful results in the conservation and promotion of the territory. This study was conducted on the basis of the opinions of 9 experts (geologists and geographers) who have deep knowledge of the geological objects of the Aktobe oblast.

The experts answered 18 questions, assessing each geological object. The questionnaire has been developed on the basis of indicators and sub-indicators (values) of the GAM methodology. This method consists of two sets of values: MV and AV. MV include scientific and educational values, scenic-aesthetics values and protection of a geological object. AV include functional and tourist values. The scientific and educational values of VSE consist of 3 sub-indicators proposed, which cannot be understood by a wide audience without additional components (Pereira, 2010; Reynard et al., 2007).
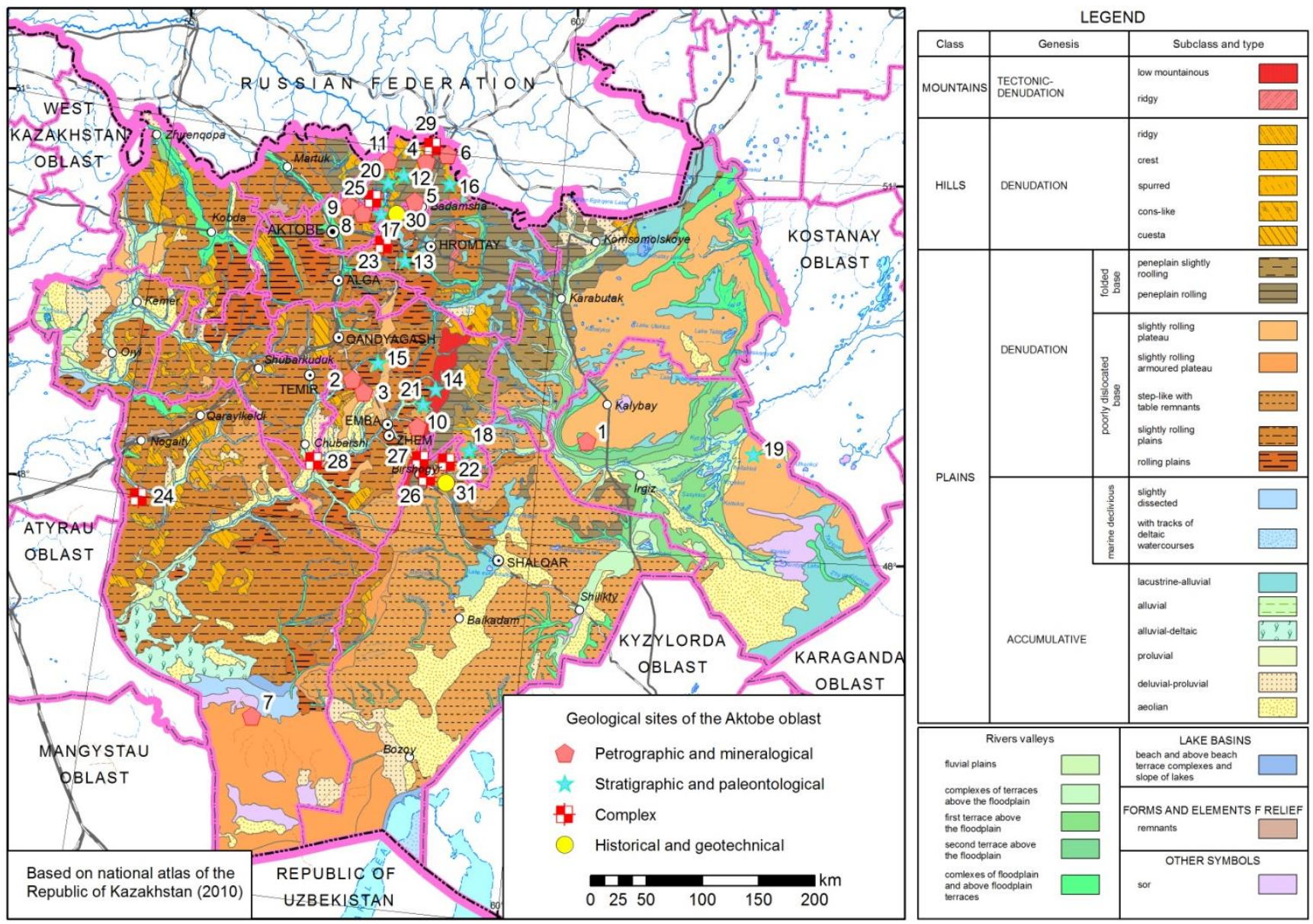

Figure 1. Geological sites of the Aktobe oblast. (Source: author's development) Petrographic and mineralogical - 1. Zhamanshin; 2. Shili; 3. Zhylansai; 4. Chaushka; 5. Kuagash; 6. Shandasha; 7. Donyztau; 8. North Alexandrovka; 9. West Petropavlovsk:

10. Massif Aulie; 11. Serpentinite melange; Stratigraphic and paleontological - 12. Coastal rivers Medet; 13. Ornectassay;

14. Kenkuys; 15. Karakol; 16. Romankol; 17. Coastal rivers Aktasty; 18. Tikbutak; 19. Shalkarnura; 20. Dombar hills; 21. Kysyltobe; Complex - 22. Shuyldak; 23. Aidarlyasha; 24. Aktolagai; 25. Coastal rivers Zhaksy Kargaly; 26. Bortebai; 27. Paleovolcano Zhalgyztau; 28. Kokzhide; 29.The gorge of the Ebeyti river; Historical and geotechnical - 30. Aktastinsky reef; 31. South Zhamantau

Scientific and educational values include the level of rarity, representativeness, knowledge and interpretation. The aesthetic values of the VSA are included in the MV because they are very important as time passes. This indicator includes viewpoints 
of sub-indicators, surfaces, surrounding landscapes and ecological improvement of objects. VPr protection is considered as the basic value as it is an important activity before the promotion and development of tourism in general. The parameters ensuring a high level of protection of geological objects are the current conditions, the level of protection, vulnerability and the permissible number of visitors. AV is divided into two indicators: functional values VFn and tourist values VTr. The functional values VFn consist of several indicators such as accessibility, additional natural values, additional cultural values, distance to the center and the proximity of important roads. They are not immediate elements of tourism, but have a direct effect on the development of geotourism. Tourist values VTr assess the current state of tourist services, including transportation, proximity of visitors to the center, number of visitors, tourist infrastructure, guide services. This method uses only $10 \mathrm{MV}$ sub-indicators and 9 AV sub-indicators, which can take numerical values: 0.00, 0.25, 0.50, 0.75 and 1.00 (for more details of model see Vujičić et al. (2011), Braholli and Menkshi (2021)). The following formula is used to determine MV:

$\mathrm{MV}=\mathrm{VSE}+\mathrm{VSA}+\mathrm{VPr}$ The formula that is used to determine AV: AV $=\mathrm{VFn}+\mathrm{VTr}$

\section{RESULTS DISCUSSIONS}

Geological routes along the outcrops of sections on the terrain involve the most representative areas of the Aktobe oblast, with their peculiar and sometimes unique objects of geological history. The description of the routes of geological excursions begins with sections of relatively young Paleogene deposits of the Eastern Caspian Sea region and the Aktobe Cis-Urals region. The outcrops of sections of Paleozoic and Proterozoic rock complexes are very diverse, they are commonly found on the territory of the Mugalzhar mountains (Baimagambetov, 2012). There are 31 geological monuments of nature in the Aktobe oblast, and 15 of them are located within the Ural-Mugodzhar mountain country, 3 ones are in the PreUral trough and the adjacent north-western slope of the Caspian syneclise. It makes up $9.4 \%$ of the total number of geological natural monuments of the Republic of Kazakhstan. Another 14 geological objects are proposed to be granted the status of regional significance: geological ones - Shili, Zhylansai, Chaushka, Kuagash, Shandasha, Donyztau, North Alexandrovka, West Petropavlovsk; paleontological ones - Medet, Ornectassay, Kenkuys, Karakol, Romankol (Figure 1). Based on the GAM method a qualitative assessment of each geological object of the Aktobe oblast was carried out. Tables 1,2 demonstrate numerical estimates of indicators and sub-indicators for each of the selected geological objects (Figure 2). Zhamanshin crater is a geomorphological meteorite crater. The diameter of the crater reaches $10 \mathrm{~km}$, there is also a less expressed outer ring. The age calculated by the radiological method makes up 12 million years. In 1939 geologists Vakhrameyev and Yanshin (1941) in the Northern Aral Sea region, composed of shallowdipping Paleogene sedimentary rocks, for the first time drew attention to a small area where Paleozoic metamorphic basement rocks were found on the surface.
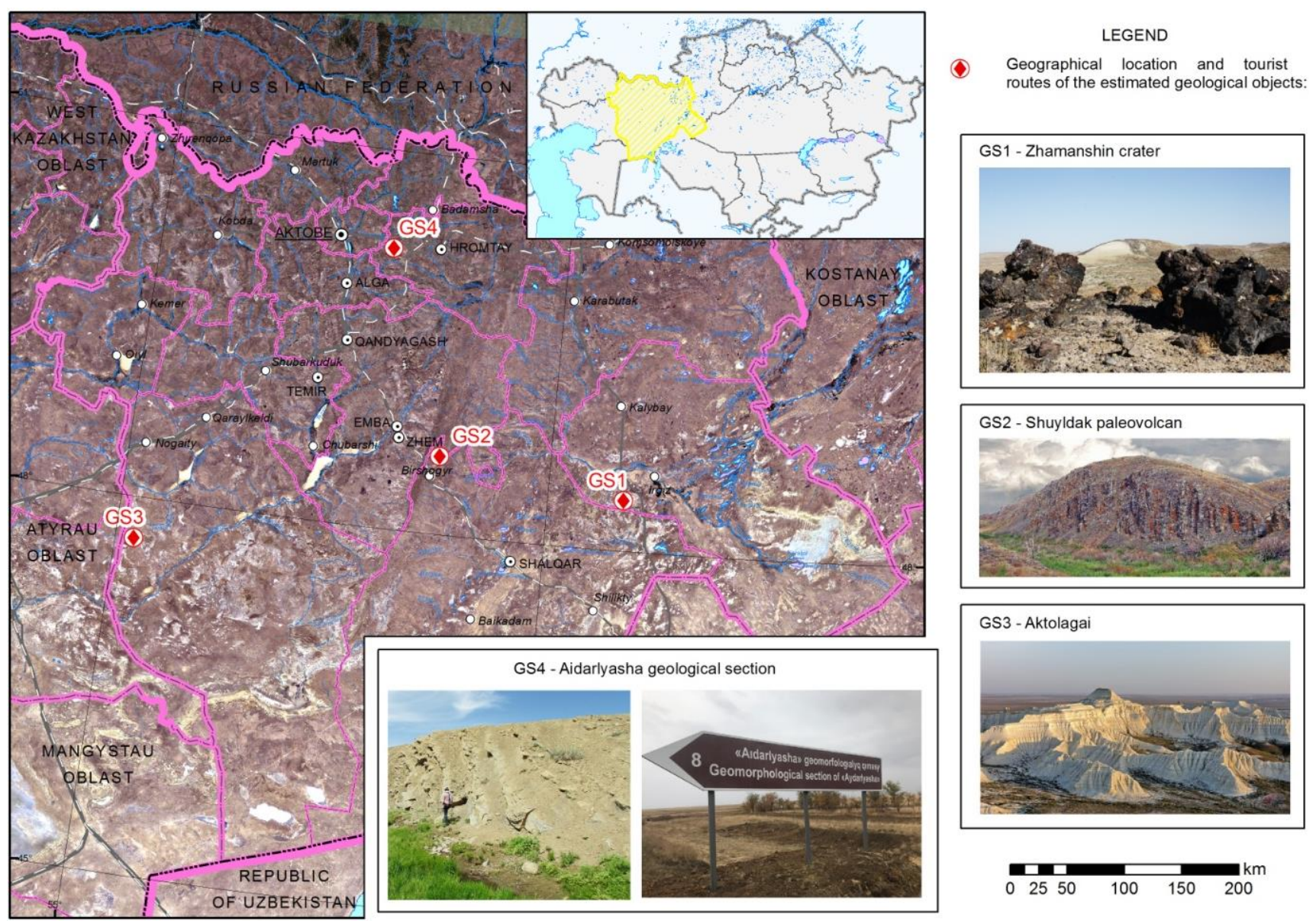

Figure 2. Geographical position of the assessed geological objects: GS 1 - Zhamanshin crater,

GS 2 - Shuyldak paleovolcan, GS 3 - Aktolagai, GS 4 - Aidarlyasha geological section. (Source: author's development) 
Table 1. Assessment of selected geological objects of the Aktobe oblast on the basis of the GAM method developed by Vujičić (2011) (Source: Result of the study)

\begin{tabular}{|c|c|c|c|c|}
\hline \multirow{4}{*}{ Indicator / Sub-indicator } & \multicolumn{4}{|c|}{ Values pointed by an expert $(0,00-1,00)$} \\
\hline & Zhamanshin crater & \begin{tabular}{|l|} 
Shuyldak paleovolcan \\
\end{tabular} & Aktolagai & "Aidarlyasha" geological section \\
\hline & GS 1 & GS 2 & GS 3 & GS 4 \\
\hline & \multicolumn{4}{|c|}{ Main values (MV) } \\
\hline \multirow{4}{*}{$\begin{array}{l}\text { I. Scientific and educational values (VSE) } \\
\text { Unique character (SIMV1) } \\
\text { Representativeness (SIMV2) } \\
\text { Level of interpretation (SIMV3) }\end{array}$} & & & & \\
\hline & 0.75 & 0.80 & 0.80 & 0.75 \\
\hline & 0.65 & 0.70 & 0.75 & 0.65 \\
\hline & 0.80 & 1.00 & 1.00 & 0.80 \\
\hline \multicolumn{5}{|l|}{ II. Scenic-aesthetics values (VSA) } \\
\hline Relief (SIMV4) & 0.45 & 0.80 & 0.80 & 0.65 \\
\hline Surrounding landscape and nature (SIMV5) & 0.35 & 0.85 & 1.00 & 0.75 \\
\hline Ecological state (SIMV6) & 0.90 & 1.00 & 1.00 & 0.60 \\
\hline III. Protection (VPr) & & & & \\
\hline Current state (SIMV7) & 0.50 & 0.60 & 0.85 & 0.50 \\
\hline Level of protection (SIMV8) & 0.00 & 0.00 & 0.00 & 0.00 \\
\hline Vulnerability (SIMV9) & 0.25 & 0.50 & 0.50 & 0.60 \\
\hline Number of visitors (SIMV10) & 0.45 & 0.25 & 0.35 & 0.50 \\
\hline \multicolumn{5}{|c|}{ Additional values (AV) } \\
\hline I. Functional values (VFn) & & & & \\
\hline Accessibility (SIAV1) & 0.25 & 0.25 & 0.25 & 0.50 \\
\hline Additional natural values (SIAV2) & 0.25 & 0.50 & 0.60 & 0.60 \\
\hline Additional anthropogenic values (SIAV3) & 0.00 & 0.00 & 0.00 & 0.00 \\
\hline Proximity to important road network (SIAV4) & 0.50 & 0.25 & 0.25 & 0.60 \\
\hline II. Tourist values (VTr) & & & & \\
\hline Organized visits (SIAV5) & 0.25 & 0.25 & 0.20 & 0.50 \\
\hline Number of visitors (SIAV6) & 0.40 & 0.20 & 0.40 & 0.50 \\
\hline Tourist infrastructure (SIAV7) & 0.00 & 0.00 & 0.00 & 0.00 \\
\hline Guide services (SIAV8) & 0.50 & 0.25 & 0.50 & 0.50 \\
\hline Services (SIAV9) & 0.00 & 0.00 & 0.00 & 0.05 \\
\hline
\end{tabular}

Table 2. Classification of selected geological objects in different zones based on the GA model (Source: Result of the study)

\begin{tabular}{|c|c|c|c|}
\hline Geological objects & Main values (VSE + VSA + VPr) & Additional values (VFn + VTr) & Overall assessment \\
\hline GS 1 & $2.2+1.7+1.2=5.1$ & $1+1.15=2.15$ & 7.25 \\
\hline GS 2 & $2.5+2.65+1.35=6.5$ & $1+0.7=1.7$ & 8.2 \\
\hline GS 3 & $2.55+2.8+1.7=7.05$ & $1.1+1.1=2.2$ & 9.25 \\
\hline GS 4 & $2.2+2+1.6=5.8$ & $1.7+1=2.7$ & 8.5 \\
\hline
\end{tabular}

The works over the last 15-20 years have proved that about 700 thousand years ago a giant meteorite fell here and the rocks of the foundation were thrown out of a 700-meter crater as a result of an explosion whose energy reached tens of thousands of megaton bombs. The pressure increased to hundreds of kilobars and megabars, when over-pressured minerals could be formed - coesite, stishovite and even over-pressured carbon - lonsdaleite, found, in particular, in a meteorite crater (Boyko et al., 2009). For many years Florensky (1980), Izokh (1990) were developing a hypothesis of the origin of tektites according to which the age of the crater is about 10 thousand years. It is one of the few deposits of tektites (irgizites) on Earth and the only crater in which tektites and impactites are simultaneously detected (Figure 3).
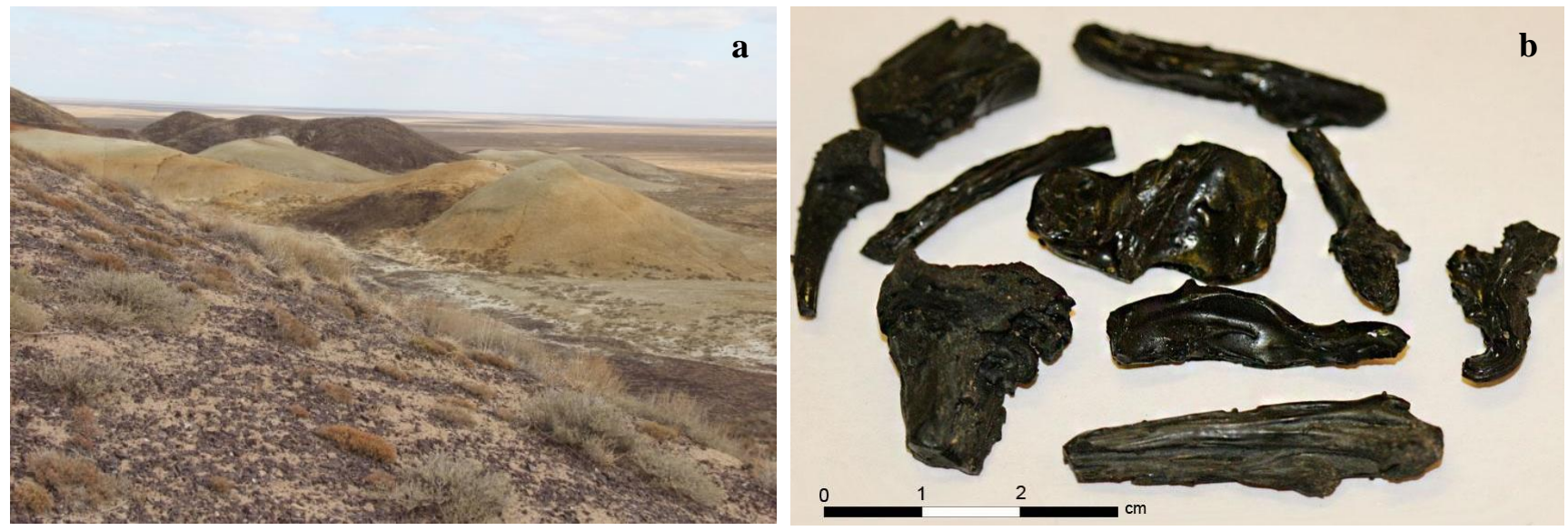

Figure 3. (a) Relief type in Zhamanshin; (b) Zhamanshinite and irgizite (Source: Authors' own)

It is is a very interesting place for scientific tourism. However there is no hotel, a comfortable place for people there. But the geotourism zone gives an opportunity to investigate the crater, which has no analogues in the world, and see the formed rocks. So far, the development of tourism in this direction is very slow. The Aidarlyasha geological section is a reference section of the boundary of the carboniferous and Permian systems, the location of the fauna of ammonoids, fusulinids, conodonts. The section is located on the right steep bank of the Aidarlyasha River (Figure 4). 

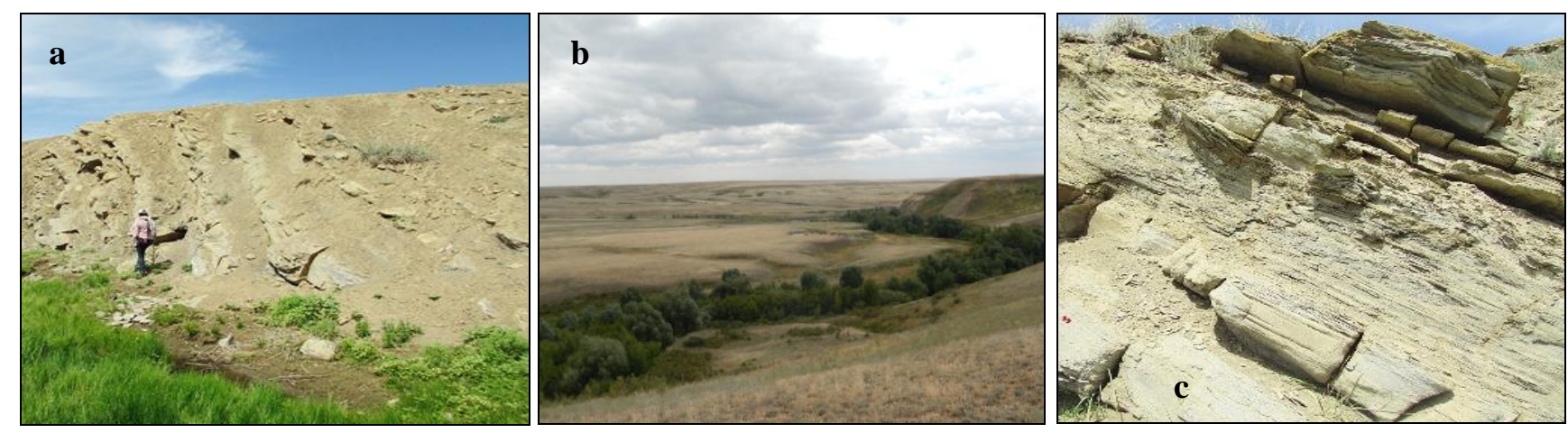

Figure 4. (a) Conglomerates of the right bank of the r. Aydarlyasha;

(b) Aidarlyash section; (c) General view of the "Aidarlyasha" geological section (Source: Authors' own)

A unique location of fossil organic remains, which are irregularly distributed in the section. The lower part of the section has a predominant content of fusulinids and conodonts, ammonoids are rare. The study of Aidarlyasha commenced since the 1950s. In 1991 on the occasion of the 150th anniversary of the discovery of the Permian system by R. I. Murchison scientists conducted studies of all geological faults referring to this period. It is known that the Carboniferous period, which lasted 350-360 million years and the Permian-Paleozoic era, which lasted 285 million years, were the last stages of that time. During the Devonian period before the Carboniferous, the weather was wet and warm, trees grew to huge sizes, trilobites, frame animals developed and at the end of the Carboniferous and Permian period the climate became arid, the previous species of animals and plants disappeared, new plants and animals came to exist adapted to the new situation. The Carboniferous and Permian periods are characterized by the disappearance of trilobites, the development of amphibians, the coming of reptiles, insects. The miracle of Aidarlyasha is not only in that, the study of the cross-section of the cut gives insight into the peculiarities of the development of each stage of the Earth's crust, to assess the potential of minerals on the territory of the Aral and Caspian Seas, the West Kazakhstan region. The valley of the Aidarlyasha River is a unique location of fossil organic remains that are in the state of a unique preservation. The section of the boundary Carboniferous and Permian layers contains information about the conditions of sedimentation, climate and the level of life development in a certain place and time. The finds in Aidarlyasha location are a vivid evidence that once a tropical sea was splashing on the territory of the Aktobe oblast and amazing animals lived. It is valuable not only as a natural monument but also gives scientists an opportunity to have a glimpse into the depths of time, to track the processes that took place in the Permian period. It was one of the most difficult periods in the history of the Earth: the process of folding was in progress, some mountains collapsed and others rose. Aidarlyasha is one of the "echoes" of that period (Abdullina et al., 2019).

The section of the Carboniferous and Permian boundary layers contains information about the conditions of sedimentation, climate, and the level of life development in a certain place and time. The section is of scientific importance for specialists in the field of geography, geology, it can serve as a place of educational internship and excursions for students of geological and geographical specialties, as well as an object for geological tourism.

The Shuyldak paleovolcano. The Shuyldak Canyon in the eastern spurs of the Mugalzhary ridge, located northwest off Shalkarteniz, penetrates a complex of volcanic rocks of the Early Paleozoic period formed in deep-water conditions (up to $3 \mathrm{~km}$ ) in the spreading zone. In other words this zone of rocks (mainly basalts) was the bottom of the Ural Sea which separated Kazakhstan and Eastern Europe (Shakirov, 2012). The formation of the Ural Sea began in the early Ordovician when a split of the eastern edge of the Eastern European continent took place, which is fixed by a volcanic series of rocks: basalts and rhyolites. In turn these volcanites are associated with coarse-grained strata typifying rifts. As a result of this split the Mugalzhar block, composed of metamorphic rocks, shifted to the east, clearing a space for the Ural Sea. The relicts of rocks of this stage are represented by an ophiolite association typical of mid-ocean ridges and rifts and indicating the expansion (spreading) of the ocean floor. Extremely good preservation in the section along the Shuyldak River provides us the opportunity to see nearly all forms of underwater lava flows and similar ones described in modern ocean rift zones. The Shuyldak River gives an opportunity of free movement on the surfaces of lava flows, to climb the tops of volcanoes and also to study volcanic structures in the section with the help of drilling wells. It results in new information about this type of volcanism. The Shuyldak paleovolcanic area is already a place for numerous scientific research, professional excursions. The Shuyldak paleovolcano the evidence of the high magmatic permeabllity characteristic for the boundaries of the Paleozoic tectonic plates. The fluid that accompanies volcanic activity provides metamorphic and metasomatic transformations of strata and ore genesis. Chalk mountains of Southern Aktolagai. The length is $90 \mathrm{~km}$, the width is 5-10 $\mathrm{km}$, the highest point is Mount Kiyakty $(217 \mathrm{~m})$. The Aktolagai plateau and adjacent territories are located in the area of typical semi-deserts between the rivers Sagiz and Zhem (Emba). The western drop-offs of the Aktolagai Southern Plateau extend to more than $16 \mathrm{~km}$, which are classical Upper Cretaceous, Paleogene and Neogene outcrops for almost the entire salt-dome region of the Peri-Caspian Depression. In the west the border is drawn in such a way that the nature reserve site covers not only the drop-offs of the Aktolagai plateau but also the terrace at the foot of the drop-offs with outcrops of Cenomanian terrigenous rocks and Turon chalk-marl rocks, as well as the Tolagaysor section (Abdullina et al., 2021; Fishman et al., 2007). The northern border is drawn taking into account the inclusion of unique outcrops of the Maastrichtian stage at the foot of the plateau drop-offs into the protection zone. There are exposures of micro-disjunctive tectonics here. The drop-offs of the plateau are composed of Paleogene rocks (Figure 5). 

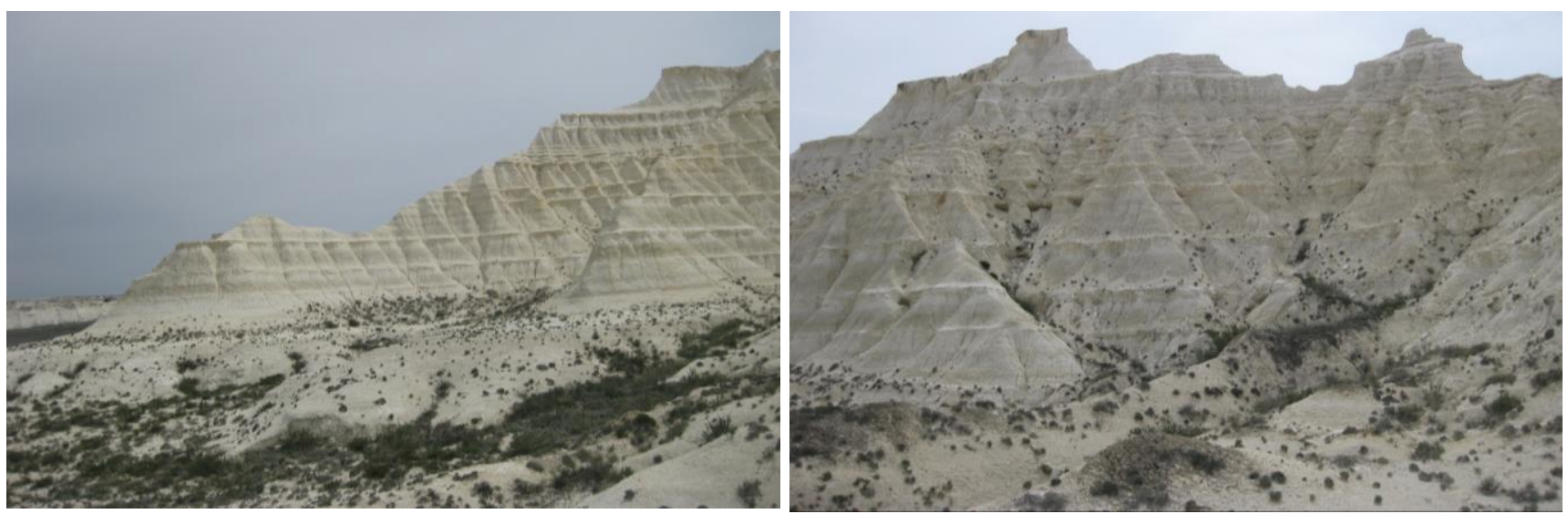

Figure 5. a) Rifts is the most spectacularly expressed in the structures of Aktolagay plateau; b) Landscape of South Aktolagai (Source: Authors' own)

Table 3. Basic Geological objects of the Aktobe oblast (Source: Result of the study)

\begin{tabular}{|c|c|c|c|c|}
\hline № & $\begin{array}{c}\text { The name } \\
\text { of the object }\end{array}$ & Description of the object & $\begin{array}{l}\text { Proposals on the measures } \\
\text { to protect the objects }\end{array}$ & Proposals on the use \\
\hline 1. & $\begin{array}{l}\text { Zhamanshin } \\
\text { (area) }\end{array}$ & Impact crater $7 * 7 \mathrm{~km}$ & \multirow{3}{*}{$\begin{array}{l}\text { To ensure the preservation in the } \\
\text { current state, to prevent construction } \\
\text { and other works related to changes in } \\
\text { the morphology of the relief }\end{array}$} & \multirow{3}{*}{$\begin{array}{l}\text { To include into advertising } \\
\text { brochures on geotourism }\end{array}$} \\
\hline 2. & Shili & Impact crater (diameter 2,5 km.) & & \\
\hline 3. & Zhylansai & Salt dome (Impact crater) & & \\
\hline 4. & \begin{tabular}{|l|} 
Shuyldak \\
(river valley \\
and left-bank \\
zone $1-3 \mathrm{~km}$ \\
wide)
\end{tabular} & $\begin{array}{l}\text { Paleovolcanic, fragments of paleovolcanic } \\
\text { buildups. Lavas of various morphology: } \\
\text { pillow, tube-shaped, reservoir ones. } \\
\text { Parallel dikes, deposits. Extrusion-lava } \\
\text { and geyser structures. }\end{array}$ & $\begin{array}{l}\text { To ensure preservation in the current } \\
\text { state, to ban construction on the } \\
\text { reservoir on the Shuyldak river, to } \\
\text { exclude mining as a building stone. }\end{array}$ & $\begin{array}{l}\text { Organization of a scientific and } \\
\text { educational training ground to } \\
\text { get insight into the structure of } \\
\text { the } 2 \text { nd layer of the paleoceanic } \\
\text { crust and paleovolcanic forms of } \\
\text { a pre-insular type of volcanism. }\end{array}$ \\
\hline 5. & $\begin{array}{l}\text { Aidarlyasha } \\
\text { (river valley) }\end{array}$ & $\begin{array}{l}\text { The reference section of the boundary of } \\
\text { the Carboniferous and Permian systems } \\
\text { approved by the international community. } \\
\text { The location of the fauna of ammonoids, } \\
\text { fusulinids, conodonts. }\end{array}$ & $\begin{array}{l}\text { To ensure the preservation in the } \\
\text { current state. To ban all types of } \\
\text { construction and the construction of } \\
\text { dams. }\end{array}$ & \multirow[t]{2}{*}{$\begin{array}{l}\text { Scientific excursions, } \\
\text { disciplined visits by tourists. }\end{array}$} \\
\hline 6. & $\begin{array}{c}\text { Southern Akto- } \\
\text { lagai (plateau) }\end{array}$ & $\begin{array}{l}\text { graphic section of the Campa- } \\
\text { ian and Eocene sediments. }\end{array}$ & $\begin{array}{l}\text { To ensure the preservati } \\
\text { current state. }\end{array}$ & \\
\hline 7. & $\begin{array}{l}\text { Aktastinsky } \\
\text { reef }\end{array}$ & $\begin{array}{l}\text { A body of light reef algal limestones } \\
\text { among the terrigenous deposits of the } \\
\text { Kungurian stage of the Lower Permian on } \\
\text { the western wing of the Belagor anticline }\end{array}$ & $\begin{array}{l}\text { Currently limestones are intensively } \\
\text { developed for industrial purposes. There } \\
\text { is a threat of complete destruction of the } \\
\text { reef. The preservation of the } \\
\text { geological object is required. }\end{array}$ & $\begin{array}{l}\text { It is of interest both for } \\
\text { geological research and mass } \\
\text { tourism. }\end{array}$ \\
\hline 8. & $\begin{array}{l}\text { Shalkarnura } \\
\text { (chinks) }\end{array}$ & $\begin{array}{l}\text { The lo } \\
\text { rhinoc } \\
\text { There }\end{array}$ & $\begin{array}{l}\text { To ensure t } \\
\text { natural stat } \\
\text { economic a }\end{array}$ & $\begin{array}{l}\text { It is of interest for professional } \\
\text { geological and paleontological } \\
\text { research. }\end{array}$ \\
\hline 9. & Dombar hills & $\begin{array}{l}\text { A limestone ridge } 4 \mathrm{~km} \text { long and about } \\
300 \mathrm{~m} \text { wide, is the richest cluster of early } \\
\text { carbon ammonoids of planetary } \\
\text { significance. }\end{array}$ & $\begin{array}{l}\text { To ensure the preservation in the } \\
\text { current state. To ban any economic } \\
\text { activity, especially the development of } \\
\text { limestones as minerals. }\end{array}$ & $\begin{array}{l}\text { It is of interest for } \\
\text { paleontological and stratigraphic } \\
\text { studies. }\end{array}$ \\
\hline 10. & $\begin{array}{l}\text { Paleovolcano } \\
\text { Zhalgyztau }\end{array}$ & $\begin{array}{l}\text { A large well-preserved andesite-dacite } \\
\text { extrusion structure with the remains of an } \\
\text { island-type volcanic cinder (blowing) } \\
\text { cone. }\end{array}$ & $\begin{array}{l}\text { To keep it in the current state. To ban } \\
\text { quarrying of building stone. }\end{array}$ & $\begin{array}{l}\text { To include into the group of the } \\
\text { Southern Mugalzhar paleovolcanic } \\
\text { polygon. To use it for } \\
\text { paleovolcanic scientific excursions. }\end{array}$ \\
\hline 11. & $\begin{array}{l}\text { Serpentinite } \\
\text { melange }\end{array}$ & $\begin{array}{l}\text { Blocks of rocks of Ordovician-Silurian } \\
\text { age among the laminated serpentinites }\end{array}$ & $\begin{array}{l}\text { To preserve and prevent mining } \\
\text { operations. }\end{array}$ & ns, objects for \\
\hline 12. & $\begin{array}{l}\text { The gorge of } \\
\text { the Ebeyti } \\
\text { river }\end{array}$ & $\begin{array}{l}\text { A picturesque gorge rich with numerous } \\
\text { rock outcrops of intrusive, metamorphic } \\
\text { and sedimentary rocks of the Precambrian } \\
\text { and Lower Paleozoic periods. }\end{array}$ & $\begin{array}{l}\text { To ensure the preservation in the current } \\
\text { state. To ban further economic activity, to } \\
\text { carry out reclamation work on destroyed } \\
\text { agricultural structures. }\end{array}$ & $\begin{array}{l}\text { To create a natural park and use } \\
\text { it for mass organized tourism. }\end{array}$ \\
\hline
\end{tabular}

The north-eastern section of the boundary of the object was chosen in such a way so as to include in the protected area a specific section of the Aktolagai plateau, relatively isolated from the southern tip of the plateau in the result of salt-dome tectogenesis. The eastern border is drawn in such a way that the entire Shiilisai salt dome is to be covered by the protection zone. Here, on the north-eastern wing, the outcrops of the Lower and Upper Cretaceous rocks are clearly traced. Magnificent outcrops of Sarmatian rocks can be observed in the steep slopes of the Terensai ravine which cut through this section of the plateau. The southern border limits the southern drop-offs and slopes of the Aktolagai plateau, composed of the Upper Cretaceous and Paleogene rocks, as well as the part of the terrace at the foot of the southern drop-offs of the plateau. Here, the buried channel of the Oligocene river, made of alluvium, has been preserved in the drop-offs of the plateau. Thus, the protection zone of the Southern Aktolagai Plateau includes not only classical sections of the Neogene, Paleogene, Upper Cretaceous; the tectonic-sedimentation negative structure of the Shiilisai - the above-roof cauldron, but also amazing denudation relief forms. Therefore, the object Aktolagai Southern Plateau is fully a geological object and to the same extent, if not to a greater one, it 
also occurs to be a geomorphological object (Koshim et al., 2021). The unforgettable landscapes, various paleontological remains and the visibility of the geological processes that took place here millions of years ago make the Aktolagai plateau very attractive not only for specialists, but also for the tourist community. Currently, the Aktolagai plateau is not included in any tourist catalog. It is easy to forecast that the popularity of the plateau as an object of mass tourism will increase in proportion to the spread of information. Over time that will give an opportunity to create the infrastructure and the necessary modern services. The development of the tourism industry, which is crucial for the Aktobe oblast, should take into account the geological structure of the territory and the availability of a large number of interesting and unique objects of geological heritage, which provide opportunities to organize geotourism. No doubt that so as to develop this sphere of industry with no negative impact on nature it is required first of all to take into consideration the objects of the geological heritage of this region, to highlight the most valuable and unique ones. And currently with no regulations for the use of geological objects in tourist activities, one can rely only on the integrity of instructors and guides who conduct routes using monuments of the geological history of the Aktobe oblast. Table 3 presents the character and proposals for the protection arrangements on geological objects. Though the Aktobe oblast is sufficiently studied from the geological point of view, at the same time it is characterized with problems of protection. The main reason is that the objects are not reflected in the schemes of territorial planning (land use), do not have cadastral registration, passports and preservation orders are not issued. A long time period from validating an order to the execution of all necessary documentation may result in the loss of the value or integrity of the objects. Thus, the ancient Alabas volcano (the "Shuyldak Paleovolcanic district" object) was partially destroyed as a result of mining operations, more over in 2011 there were 5 plants engaged in the extraction of crushed stone in the Shalkar district. The object "Algal reef limestones of Lower Permian of the Aktastinsky reef" is also being developed by an open-pit method. Currently the northern, eastern and western parts of the reef body are partially preserved and the southern part has been worked out by a quarry for building materials. The exposed walls of the quarry give an opportunity to have a qualitative study of the internal structure of the reef body. In addition to the effective protection of the objects listed above the official approval of the nature protection status for promising natural monuments of regional significance is of much importance. In our opinion an additional inventory of geological objects is required. One of the objects to be claimed for the nature protection status is the top of the Mugalzhar ridge - the mountain Bolshoy Boktybai $(657 \mathrm{~m})$, located in an area of intensive mining production.

\section{CONCLUSION}

The main role in the formation, preservation and destruction of the diversity of the Earth's subsurface and landscapes is played by endogenous and exogenous geological processes due to their power and duration, which cannot be compared with the duration of human existence as a biological species. However, in the last 50 years, both anthropogenic and technogenic processes have begun to influence the formation of geo-diversity. So far, these human impacts on the Earth of the territory of the Aktobe oblast as a geological body affect only the lithosphere and are carried out in the following main directions:

- geological study, evaluation and exploration of mineral deposits (carried out without significant violation of the subsurface integrity);

- mineral production.

Aktobe oblast is very rich in geological and geomorphological heritage. But many geological objects are not subject to protection. Geological heritage is often a place of significant tourist and recreational potential. The effective implementation of the principles of geotourism, the promotion of geotourism and geo-heritage can decisively contribute, on the one hand, to the development of tourism and, on the other hand, to the protection of natural heritage. The stable high growth dynamics of the Aktobe oblast is closely related to the development of production, which involves the richest mineral resources in the economy, there is an interaction of natural and artificially created elements, providing the appearance of changes in the environment. In this regard, due to the limited work and collaboration between current biodiversity activists and Earth scientists, it is important to integrate and link biotic and geological conservation. Human activity has greatly changed the character of the natural landscapes of the Aktobe oblast and Kazakhstan as a whole. There is practically no landscape that has not experienced at least indirectly the influence of human economic activity. Priority in the organization of new specially protected areas are given to the areas with the greatest concentration of wildlife and inorganic nature that require special protection, which will be of help for Kazakhstan to preserve its priceless wealth.

\section{REFERENCES}

Abdullin, A.A. (1981). Geologiya Kazakhstana [Geology of Kazakhstan], Nauka, Almaty, Kazakhstan.

Abdullina, A.G., Saparov, K.T., Sergeyeva, A.M., Yeginbayeva, A.Y., \& Atasoy, E. (2019). The importance of toponymy of Mugalzhary Mountain plots and adjacent territories to the development of geoturism. GeoJournal of Tourism and Geosites, 25(2), 664-674. https://doi.org/10.30892/gtg.25230-388

Abdullina, A.G., Sergeyeva, A.M., Saparov, K.T., Shumakova, G.Z., Yeginbayeva, A.Y., \& Embergenov, N.J. (2021). Toponyms of cretaceous deposits in Western Kazakhstan territory (in the context of Aktobe region). News of the National Academy of Sciences of the Republic of Kazakhstan, Series of Geology and Technical Sciences, 2(446), 22-30. https://doi.org/10.32014/2021.2518-170X.30

Badiali, F., Ilieş, D.C., \& Castaldini, D. (2018). A tale of a city, through its urban landscape and cultural heritage in the heart of Europe: The case study of Oradea city (Romania). Geojournal of Tourism and Geosites, 2018, 21(1), 88-102

Baimagambetov, B.K. (2012). Putevoditel geologicheskikh e`kskursij [Geological Excursions Guide], Nobel, Aktobe, Kazakhstan.

Boyko, Y.I., Korobkov, V.F., Baimagambetov, B.K., Sapozhnikov, P.K., \& Ulukpanov, K.T. (2009). Astroblema Zhamanshin: nerealizovanny`e i predstoyashhie zadachi issledovanij [Astrobleme Zhamanshin: outstanding and forthcoming research problems], Uralsky geologichesky zhurnal, 6 (72), 40-50.

Braholli, E., \& Menkshi, E. (2021). Geotourism potentials of geosites in Durrës municipality, Albania. Quaestiones geographicae, 40(1), 63-73. https://doi.org/10.2478/quageo-2021-0005

Bruno, D.E., Crowley, B.E., Gutak, J.M., Moroni, A., Nazarenko, O.V., Oheim, K.B., Ruban, D.A., Tiess, G., \& Zorina, S.O. (2014). Paleogeography as geological heritage: Developing geosite classification. Earth-Science Reviews, 138, 300-312. https://doi.org/10.1016/j.earscirev.2014.06.005

Castaldini, D., \& Coratza, P. (2017). Mud Volcanoes in the Emilia-Romagna Apennines: Small Landforms of Outstanding Scenic and Scientific Value. World Geomorphological Landscapes, 225-234 DOI 10.1007/978-3-319-26194-2_19 
Comanescu, L., \& Dobre, R. (2009). Inventorying evaluating and tourism valuating the geomorphosites from the central sector of the Cealhau National park. GeoJournal of Tourism and Geosites, 1(3), 86-96.

Comănescu, L., Nedelea, A., \& Stănoiu, G. (2017). Geomorphosites and Geotourism in Bucharest City Center (Romania). Quaestiones Geographicae, 36(3), 51-61. https://doi.org/10.1515/quageo-2017-0029

Coratza, P., Reynard, E., \& Zwoliński, Z. (2018). Geodiversity and Geoheritage: Crossing Disciplines and Approaches. Geoheritage, 10(4), 525-526. https://doi.org/10.1007/s12371-018-0333-9

Fishman, I.L. (2016). Geodynamic models of the Aral-Caspian region, Kazakhstan geological society "KAZGEO", Academy of mineral resources of Republic of Kazakhstan, Almaty, Kazakhstan.

Fishman, I.L., Kazakova, Y.I., \& Kamensky, A.S. (2007). Geologicheskoe obosnovanie sozdaniya geoparkovna territorii RK [Geological justification of the creation of geoparks on the territory of the Republic of Kazakhstan], Kazgeoinform, Almaty, Kazakhstan.

Florensky, P.V., \& Dabizha, A.I. (1980). Meteoritny`j krater Zhamanshin [Zhamanshin meteorite crater] Nauka, Moskva, Russia.

GaŁka, E. (2019). Geotourism regions - delimitation, classification, basic concepts. Geographia Cassoviensis, 13(2), 180-195. https://doi.org/10.33542/GC2019-2-05

Ghazi, J.M., Ólafsdóttir, R., Tongkul, F., Ghazi, \& J.M. (2013). Geological Features for Geotourism in the Western Part of Sahand Volcano, NW Iran. Geoheritage, 5(1), 23-34. https://doi.org/10.1007/s12371-012-0071-3

Gill, J.C. (2017). Geology and the Sustainable Development Goals. Episodes, 40 (1), 70-76. https://doi.org/10.18814/epiiugs/2017/v40i1/017010

Gray, M. (2004). Geodiversity: Valuing and Conserving Abiotic Nature, Publishing company profile, John Wiley \& Sons, Ltd., Chichester, West Sussex, United Kingdom.

Hadmoko, D.S., Marfai, M.A., Malawani, M.N., Mutaqin B.W., Risanti, A.A., \& Permatasari, A.Z. (2021). Coastal geomorphosites assessment for ecotourism development in east Lombok, Indonesia. GeoJournal of Tourism and Geosites, 36(2 spl), 589-596. https://doi.org/10.30892/gtg.362spl05-687

Hurtado, H., Dowling, R., \& Sanders, D. (2013). An Exploratory Study to Develop a Geotourism Typology Model. International Journal of Tourism Research, 16 (6), 608-613. https://doi.org/10.1002/jtr.1954

Ilieș, D.C., Caciora, T., Herman, G.V., Ilieș, A., Ropa, M., \& Baias, Ș. (2020). Geohazards affecting cultural Heritage Monuments. a complex case study from Romania. GeoJournal of Tourism and Geosites, 31(3), 1103-1112. https://doi.org/10.30892/gtg.31323-546

Izokh, E.P., Kashkarov, L.L., \& Genayeva, L.I. (1990). Vozrast styokol udarnogo kratera Zhamanshin po danny'm trekovy $m$ issledovanij [The age of the glasses of the Zhamanshin impact crater according to the data of track studies], Nauka, Novosibirsk, Russia.

Kiernan, K. (2015). Landforms as Sacred Places: Implications for Geodiversity and Geoheritage. Geoheritage, 7, $177-193$. https://doi.org/10.1007/s12371-014-0128-6

Koshim, A.G., Sergeyeva, A.M., Bexeitova, R.T., \& Aktymbayeva, A.S. (2020). Landscape of the Mangystau region in Kazakhstan as a geomorphotourism destination: a geographical review. GeoJournal of Tourism and Geosites, 29(2), 385-397. https:/doi.org/10.30892/gtg.29201-476

Kubalíková, L. (2013). Geomorphosite assessment for geotourism purposes. Czech Journal of Tourism, 2(2), 80-104. https://doi.org/10.2478/cjot-2013-0005

Manyuk, V. (2016). Study and Preservation of Geosites: a Training Course for Geology Students in the Ukraine. Geoheritage, 8(2), 181187. https://doi.org/10.1007/s12371-015-0147-y

Mikhailenko, A.V., Ermolaev, V.A., \& Ruban, D.A. (2021). Bridges as geoheritage viewpoints in the Western Caucasus. Geosciences, 11(9), 377. https://doi.org/10.3390/geosciences 11090377

Mirari, S., \& Benmlih, A. (2020). Promotion of geotourism and geoheritage at the oases of oued noun. GeoJournal of Tourism and Geosites, 32(4), 1433-1440. https://doi.org/10.30892/gtg.32435-591

Newsome, D., Dowling, R., \& Leung, Y.F. (2012). The nature and management of geotourism: A case study of two established iconic geotourism destinations. Tourism Management Perspectives, 2-3, 19-27. https://doi:10.1016/j.tmp.2011.12.009

Ólafsdóttir, R., \& Tverijonaite, E. (2018). Geotourism: A Systematic Literature Review. Geosciences, 8(7), 234. https://doi.org/10.3390/ geosciences8070234

Panizza, M. (2001). Geomorphosites: Concepts, methods and examples of geomorphological survey. Chinese Science Bulletin. 46, 4-5. https://doi.org/10.1007/BF03187227

Panizza, M., \& Piacente, S. (2008). Geomorphosites and geotourism. Revista Geográfica Acadêmica, 2(1), 5-9.

Pereira, P. (2010). Methodological giudelines for geomorphosite assessment. Geomorphologie, 16(2), 215-222. https://doi.org/10.4000 /geomorphologie.7942

Pourfaraj, A., Ghaderi, E., Jomehpour, M., \& Ferdowsi, S. (2020). Conservation Management of Geotourism Attractions in Tourism Destinations. Geoheritage, 12, 80. https://doi.org/10.1007/s12371-020-00500-4

Pralong, J.P. (2005). A method for assessing the tourist potential and use of geomorphological sites. Geomorphologie: Relife, Processus, Environnement, 3, 189-196. https://doi.org/10.4000/geomorphologie.350

Reynard, E. (2005). Géomorphosites et paysages. Geomorphologie: Relife, Processus, Environnement, 3, 181-188. https://doi.org/ $10.4000 /$ geomorphologie. 338

Reynard, E., Kozik, L., \& Scapozza, C. (2007). A method for assessing "scientific" and "additional values" of geomorphosites. Geographica Helvetiva, 62(3), 148-158. https://doi.org/10.5194/gh-62-148-2007

Ruban, D. (2015). Geotourism - A geographical review of the literature. Tourism Management Perspectives, 15, 1-15. https://doi.org/ 10.1016/j.tmp.2015.03.005

Santangelo, N., \& Valente, E. (2020). Geoheritage and Geotourism resources. Resources, 9(7), 80. https://doi.org/10.3390/resources9070080

Segedin, R.A. (2002). Rasskaz o geologii Aktyubinskoj oblasti i bogatstvakh ee nedr [The story about the geology of Aktobe region and the wealth of its subsoill, Nobel, Aktobe, Kazakhstan.

Seyitov, N., \& Zhunisov, A.A. (2002). Qazaqstan geologiyasy` [Geology of Kazakhstan], KazNTU, Almaty, Kazakhstan.

Shakirov, A.V. (2012). Fiziko-geograficheskie osobennosti i rajonirovanie Mugodzhar [Physical characteristics and zoning of Mugodzhary]. In the materials of the sixth international symposium and of the eighth international school-seminar of young scientists «Geoenvironmental problems of the steppe regions», Orenburg, Russia, p. 805-809.

Štrba, L., Kolackovská, J., Kudelas, D., Kršák, B., \& Sidor, C. (2020). Geoheritage and geotourism contribution to tourism development in protected areas of Slovakia-theoretical considerations. Sustainability (Switzerland), 12(7), 2979. https://doi:10.3390/su12072979

Vakhrameyev, V.A., \& Yanshin, A.L. (1941). Paleozoj v Severnom Priaral'e [Paleozoic in the Northern Aral Sea region]. Report of the USSR Academy of Sciences, 30 (9), 818-821.

Vujičić, D.M., Vasiljević, A.D., Marković, B.S., Hose, A.T., Lukić, T., Hadžić, O., \& Janićević S. (2011). Preliminary Geosite Assessment Model (GAM) and its application of Fruska Gora Mountain, Potencial Geotourism destinacion of Serbia. Acta Geographica Slovenica, 51(2), 361-377. https://doi.org/10.3986/AGS51303

Wendt, J.A. (2020). Directions and areas of tourism research in Kazakhstan. Geojournal of Tourism and Geosites, 32 (4), $1418-1424$. https://doi.org/10.30892/gtg.32433-589

Williams, M.A., McHenry, M.T., \& Boothroyd, A. (2020). Geoconservation and Geotourism: Challenges and Unifying Themes. Geoheritage, 12, 63. https://doi.org/10.1007/s12371-020-00492-1 